\title{
Symbols of Sacred Art in the Corporate Identity of Insurance Companies
}

\begin{abstract}
This article examines the development of the insurance business in Ukraine and Poland from the late nineteenth to the early twenty-first centuries. It identifies special aspects of the formation and use of elements of sacred art in the corporate identity of insurance companies. Dniester Mutual Insurance Company and Florianka Krakow Mutual Insurance Company are a particular focus. Examples of the use of images of St. Florian, crosses and the inscription "In the name of the Lord" in corporate identity of insurance companies are provided.
\end{abstract}

Keywords: mutual insurance, insurance company, corporate identity, elements of sacred art, cross, St. Florian.

JEL Classification: M31, M37, N2, G22.

\section{Introduction}

The evolution of the insurance industry in different countries shows how insurance companies have developed a whole system of activities aimed at attracting clients in order to strengthen, renew, and extend their insurance portfolios. K. Voblyy has called these activities "the elements of acquisition techniques" (Voblyy 2001, p. 63) and first and foremost include advertising in its various

Viktor Trynchuk, Institute of Postgraduate Education and Business, Department of Insurance, Yevhen Sverstiuk 11B,02660 Kiev, Ukraine, e-mail: victor_trinchuk@mail.ru 
forms. Other marketing communications tools should be included among acquisition techniques, and due consideration should be given to corporate identity, one of the most modern and important forms of advertising. Among the elements of the marketing mix - the 7 Ps - researcher E. Kutskei identifies material characteristics of insurance services as proof of quality for the client (external and internal decoration of offices, furniture, appliances, brochures, letterhead, employee clothing, logo) (Ubezpieczenia... 2009, p. 97). According to M. Plonka, an insurer's corporate identity and the availability of its services play the leading role in the structure of its marketing mix (Marketing... 2011, p. 31).

The experience of foreign and domestic insurers in the market confirms the need to pay due attention to developing a corporate identity that characterises and reflects the company's uniqueness and individuality. On the basis of corporate identity, policyholders are able to associate specific insurance services with the insurer's operations, and compare the forms and methods of the insurer's work and its competitors. Carefully managing one's trademark is a means of building competitive advantage (Komunikowanie... 2002, p. 131).

A number of authors have illustrated the correlation between how well a company is recognised, its trademark, products, and its market share (Strategie... 2002, p. 108).

An insurer's corporate identity is one of the most modern and important marketing communication tools it can use. It is the basis for communication policy, a main means of attracting clients, an essential element of branding, and a specific "information carrier" which helps policyholders navigate the market and advertising, and simplify the process of making choices.

Among the functions of corporate identity, the following are usually distinguished: image-building (forming and supporting an original and attractive image, increasing company prestige and reputation, widening the recognition of the insurer and its services, brand creation); identification (contributing to the identification of insurance products and advertising and indicating their relationship with the company and their origin); differentiation (distinguishing the company's products and advertising from those of other companies).

The following elements make up a company's corporate identity: trademark, logo, firm block, corporate slogan, corporate colour or combination of colours, corporate typefaces, corporate printing "lockups", unified musical themes. In addition to these basic elements, insurers can use business documentation, advertising and printed materials, various elements of outdoor advertising and branded souvenirs.

Other studies have presented a variety of views among scientists and practitioners regarding the use of insurance companies' corporate identity in communication policy. The elements of sacred art - art closely associated with faith in God and the symbolism of divine power - in the corporate identity of insurance 
companies has not been among those views. The object of the study is the corporate identity of insurance companies and its place in the system of marketing communications. The subject of the study, more specifically, is the elements of sacred art (religious symbols) in the corporate identity of insurance companies and their role in the communication process. The main objective of the study is to generalise the experience, and identify and substantiate the main features of the use of elements of sacred art in the corporate identity of insurance companies in the light of historical and economic development.

The theoretical basis used in the article were the provisions of the evolution of economic history. The methodological basis of the research is a set of methods of scientific knowledge: historical description, analysis, comparison, periodisation and chronology, all of which are used in the process of studying the history of a number of insurance companies from Ukraine, Russia and Poland. The article also examines the use of their religious and historical symbols as part of their identities (corporate style). This allowed for an impartial study of historiography, the discovery and use of a large number of documentary sources, while the methodological principles provided a practical understanding of the object of research.

In the article, the following are used: analysis and synthesis in formulating conclusions and generalisations; induction, deduction and the dialectical method of cognition in studying how the elements of sacred art manifest themselves in the corporate styles of insurers. Great importance is also attached to socio-historical methods, including socio-structural and psychological analysis.

The chronological framework of the study covers the period from 1185 to the present day.

\section{Sacred Art Is Symbolic Art}

The whole ideology, culture and literature of Christianity and other religions is deeply symbolic. It is difficult not to agree with advertising experts when they observe that symbols trigger the emergence of ideas in the human mind. The sacred-holy-saint triad (Lat. sacer) is an ideological category characteristic of an object, the presence of which puts such an object in a position of exceptional importance and value, and therefore evokes reverence (Novaya... 2001).

As Y. Shcherbakova has noted, numerous traditional values of human existence have for millenia been communicated using religious symbols (Shcherbakova 2007, p. 3). It therefore makes sense for insurance companies to use the elements of sacred art in their marketing communications as these companies are founded and being developed. 
O. Gubnitsyna is correct in writing that religion should be regarded as a value-motivational model of behaviour that helps the individual navigate society. Indeed, over the past two centuries, sacral elements have been widely used in media, advertising and PR-technologies, to name three (Gubnitsyna 2007, p. 77).

According to S. Pylypenko, the media is a major factor in transforming modern culture. It also connects culture and globalisation. This relationship is a distinguishing characteristic of the modern information society, where the destruction of classical values can be observed (Pylypenko 2012).

One can today speak of religious media - a separate, specific field of modern religion, generated by the media culture (Ryzhov 2006). Modern mass media effectively uses sacred images and concepts, a fact most clearly demonstrated by techniques and methods of advertising. To add special importance to any product, trademark or brand, it is correlated with the material values or transcendental reality and universal space.

P. Busalaev, an icon painter from Moscow, compares the whole spectrum of methods used in advertising, PR and other marketing communication tools with the system of "pseudo-sacraments", which form "a pseudo-reality" or "illusory feast". This reality is constantly maintained and reproduced by billboards placed to instil a sense of constant delight to everyone, a feeling that there are supernatural realities. Advertising slogans extensively use passages from the Gospel, the commandments of God, references to material and ethereal reality and higher powers.

Religious motifs flash in advertising found in countries throughout the world. Items with the cross are in vogue in clothing and women's jewellery and accessories, showing that religious themes have their place even in consumer goods (Drey 2013, p. 67). Unusual prints in the fall-winter 2013-2014 collections of clothes of known fashion designers embodied church themes in the Byzantine style in their clothes.

Stories and images from the Old Testament have trended. For example, in 2008 the Dutch insurance company Centraal Beheer Insurance and agency DDB Amsterdam launched a promotional video entitled Adam and Eve, with Eve meeting Adam, who is, to her surprise, gay. The insight appeals to the importance of "insurance" for unexpected cases. At the same time it is worth noting that the use of religious images in advertisements is a dangerous practice, walking the line of what some will tolerate morally, though such practices nonetheless remain very alluring (Linder 2010, p. 67).

We must remember that under conditions of global unification, religious symbols in advertising can on the one hand enhance their value by building up layers of meaning, but at the same time lose part of their meaning, which can strip one aspect of national cultural heritage. 
The sociocultural content of symbols in the advertisements of insurance companies largely determines how those ads are understood and perceived. When the mean of a symbol is inconsistent with the basic idea of an advertising message, negative attitudes may surface towards the insurance products being advertised and the company.

In her advertising discourse, L. M. Khavkina (2012, p. 324) outlines archetypical and cultural groups of symbols. Meanwhile, the specificity of religious symbols, according to M. Fedorova (2014, p. 233), lies in their ability to draw a close link between myth (creed) and ritual (religious activity) through the integration of multiple realities (sacred and social).

It is difficult not to agree with A. Leshchenko (2016, p. 49) that humans today, in spite of the enormous scientific advances and secularisation processes that have occurred, often turn to religion. Christianity, a religion which has not lost its influence on the thoughts, feelings, and experiences of humans for thousands of years, is no exception. The use of elements of sacred art as a means of translating the basic ideas of the Christian faith contribute to a more intense effect on the inner world of the religious person, which was actively used and continues to be used in insurance marketing.

Insurers have always had a professional sympathy for the theme of sacred art: "Protect and preserve", "The fire does not burn", "In the name of the Lord", etc. Religious symbols are very important for marketing communications because they carry sacred meaning. At the same time, religious symbols are used to convey the cultural experience of the population by forming rules, values and stereotypes (Shcherbakova 2007, p. 16). Perhaps this is why icons, images and the names of saints, crosses and other items of sacred art can be found in the corporate identity of insurance companies in Ukraine, Russia and Poland, mong others. Each of the above elements has been given due consideration in this study.

\section{Images of Saints as an Element of Corporate Identity}

Rescue workers of Southern Germany, Austria, Czech Republic, Slovakia, Western Ukraine, Poland, and the United States have considered St. Florian their patron. It is believed that St. Florian helps during natural disasters: fires, windstorms, drought, soil infertility, and is a patron of many professions: brewers, firemen, metallurgists, glass-makers, soap-boilers, chimney sweeps, bakers, coopers and potters. According to the legend, Florian put out a fire in a burning house with just a single jar of water, so he came to be seen as the patron of those whose occupations were associated with fire. 
In iconography, St. Florian is depicted as a Roman legionnaire with a vessel used to extinguish fire, or with a millstone, sometimes holding banners in his hands, and also as a prince. His attributes include millstone, mail, a red and white cross, a sword, the palm of the martyr, a burning house, an eagle, a shield, and weapons.

The first church of St. Florian was built in Kleparz in 1185, while the one that stands there today was built in the fourteenth century. That is why, in honour of the Holy Great Martyr Florian, in the Middle Ages the suburb of Krakow known as Kleparz was called Florence.

The architecture of the church is very unusual because it has undergone major changes during its history, being constantly rebuilt. So it is possible to see the stages of its history from the seventeenth century, when it was rebuilt after a fire. The sculpture of the martyr St. Florian, made by the artist F. Mangoldt, adorns the centre of the facade. The painting of St. Florian inside the church is a masterpiece. A gate leading to the historic centre of the city was named after St. Florian and is considered the beginning of the Road of Kings, and also the street that connects the gate with the Market Square, where solemn and mournful processions were held.

Florian Gate (St. Florian's Gate) in Krakow is the medieval gate of a tower, located in the Old Town at the end of Florian Street, as it intersects with Pijarska Street. It is the remaining part of the old city walls which surrounded Krakow in the thirteenth and fourteenth centuries. This is one of the eight gates of Krakow's defence. Florian Gate, which was mentioned in written records of 1307, was one of the gates in the city wall. The road from the church of St. Florian went through the gate, as did the cortèges of kings and foreign ambassadors as they proceeded to Wawel Castle. In Krakow, the Road of Kings begins from the Church of St. Florian, located on Warsaw Street and the corner of Matejko square.

If you enter the city through the Florian Gate, you will see a Baroque bas-relief in the wall - a statue of St. Florian. The bas-relief depicting a smiling martyr with a bucket, pouring water on a miniature church, appeared in this niche in the eighteenth century. The oldest image of St. Florian (featured in armour and a cloak) in Poland remained on the seals of the Krakow City Council, dated 1485. In his right hand he holds a banner, and in his left an oblong shield decorated with a cross. On the seals of the sixteenth century, St. Florian holds a bucket in his right hand and a spear in his left.

In Poland, St. Florian is most often depicted with a vessel filled with water, which he used to save the church and part of Kleparz from the huge fire of 1528 that swept Krakow. Florian became the defender from fire, and has since been honoured as such.

When travelling through Krakow, one can see St. Florian at 40 Grodzka Street, where the "Pod Kozłem" house stands. The building was built in the second half 
of the eighteenth century and is decorated in neo-rococo style, particularly the façade and loft, where there is a bas-relief of St. Florian. The patron of fire became even more powerful in the works of Italian masters, who depicted him not only extinguishing fires but also battling passions and sins, as evidenced by the presence of the statue of Florian in the chapel of King Sigismund in Wawel Castle.

The first Polish insurance company, the Krakow Fire Mutual Insurance Company, was established on November 29, 1860, and it is not surprising that it received the popular name "Florianka" (Knyt 2003). Since the Fire Mutual Insurance Company took the image of St. Florian, the protector from fire (Monografia... 1886, pp. 31-32), it became a symbol in the daily life of the inhabitants of Krakow as well as an element of corporate identity. The image of St. Florian can be seen on insurance policies, premium receipts, monographs, the company's charter, and in other advertising. The policy also had the inscription "In the name of the Lord" (Kałkowski 2014, p. 182).

The figure of Florian and the name of the insurance company were inscribed on insurance boards, which were usually nailed to the house, above the entrance. Insurance boards not only certified that the owner had an insurance policy against fire for his property, but also emphasised his high social status (Akimov \& Borzykh 2002, p. 15). The boards also advertised the insurance company while functioning as sacred images and amulets, silently protecting property from fire as effectively as a lightning rod during a thunderstorm. The logo of the agency department of the company was placed in a well seen place on the building where the office was located (Instrukcya dla sub-agentów... 1888, p. 7).

Landowner F. Tshecheski was the initiator of the establishment of the Krakow Mutual Insurance Company, as well as a number of libraries and cheap publishers. In 1842, during a meeting of the Sejm, he raised the issue of establishing an insurance company, though that never came to pass (Broński 2011, p. 109). Later, a separate project to create a company was presented in Lviv (1859), which was also rejected by the government in Vienna in 1859. In 1860, Tshecheski was elected as the company's curator for life. On October 20,1860, a permit for the company's operations was issued, and on November 26, 1860 the founding meeting was held and a Board of Directors elected. The Company operated within the framework of Galician autonomy. The Company's activities included providing fire insurance (initially this definition was included in the title), and, after 1864, hail insurance.

In 1864, under the initiative of the company, the first voluntary fire service was founded on Polish territory in Krakow (Iwanicz-Drozdowska 2013, p. 52). Later, Polish fire-fighters started using the image of St. Florian, leading them to be dubbed "the Knights of St. Florian", or "the Florians". Even today, fire services in many countries actively use the image of St. Florian on their branded products. In 1866, the first savings bank in Krakow, and the fourth in Galicia, was opened. 
On November 1, 1869, a life insurance department was opened to sell insurance products, without medical examination, and insurance in case of death for the purpose of payment of funeral services. Thanks to reinsurance treaties, the insurer had the ability to insure objects without limitation of the sum insured (Współczesne... 2013, p. 48).

Because its product line was expanding, the company removed fire and hail from its name. The company had also entered into agreements with foreign companies to represent their interests and implement mediation services on the territory of the Kingdom of Poland. Additionally in 1869, the company lobbied for the establishment of a credit institution.

In 1874, Florianka changed its official name to the Krakow Mutual Insurance Company. Originally the company sold policies in Galicia, Krakow, and Bukovina, then later it expanded to Volyn, Podolia, and Ukraine (Rutkowska 2006, p. 46). The Company opened a representative office in Lviv and supervised operations in Eastern Galicia and Bukovina. During the period of Austrian rule, the insurance market was developing more freely. In contrast to the Prussian and Russian rule, compulsory insurance was not introduced here; the whole market was allowed to operate upon private initiative.

After 1885, Florianka Mutual Insurance Company was located in the group of buildings at 6-8 Bashtova Street in Krakow, which were built in the middle of the nineteenth century. Today, the address is home to a music school. The buildings of Florianka were built among gardens, which from 1728 belonged to the bishops of Krakow and the Order of the Piarists. Part of the land was bought in 1845 by A. Vysotsky. The buildings were built in the Renaissance Revival architecture style. The facade of Bashtova Street is decorated with a notched parapet and statue of St. Florian.

The cult of veneration of St. Florian is quite significant. His images, in the form of paintings and sculptures, may be found in the collections of many museums and churches, on the banners of fire brigades, and carried by pilgrims. In 1898, Archbishop of Gniezno and Poznan, Florian Stablevsky, founded the Insurance Association of St. Florian for priests in Poznan.

In one of the most economically developed regions of the Russian Empire, the local manufacturer, businessman, and landowner L. Cronenberg founded the Polish insurance company. In 1870, the Warsaw Fire Insurance Company was established, which also initially used the image of St. Florian as an element of its corporate identity. Later this visual image disappeared from the policies and insurance boards: only the name and date of the foundation of the company was used. On insurance policies from 1912 and renewal policies from 1913 St. Florian is no longer found, having been replaced by a siren (mermaid) (Ivankin 2009, pp. 22-23), an image which is both a symbol of Warsaw and its coat of arms. 
The Warsaw siren is a woman with a fish tail; she holds a round shield in her left hand and a short sword in her right.

A wave of new insurance companies and insurance associations also took place in the second half of the nineteenth century in the Czech Republic. In 1868, in the town of Cheb, the Insurance Company of Fire Guild named after St. Florian was established.

In 1992 in Poland, a mutual insurance company was organised. It used the elements of Florianka Mutual Insurance Company policies with the image of Florian on its website and in print advertising. The Florian Mutual Insurance Company also operated also operated from 1999 to 2005. The Company continued the tradition of mutual insurance created on Polish territory in the mid-nineteenth century. The idea of establishing the Florian Mutual Insurance Company arose during the X congress of voluntary fire brigades of the Polish Republic in 1997 (Towarzystwo... 2001). In 2007, Florian Mutual Insurance Company was removed from the state register. The insurance portfolio was transferred to the HDI Samopomoc SA insurance company.

In Russia, the Insurance Company of St. Andrew the First-called Limited Liability Company, operated until May 5, 2014. On the domestic insurance market, the company went by the title The Insurance Company of St. Andrew the First-called, a name chosen not by chance: Apostle Andrew the First-called has long been revered as the patron saint of the Russian land and all its inhabitants. It wrote, "We see our vocation in continuing the tradition of Russian insurance, making insurance protection closer, more accessible, and more important for the majority of Russian citizens" (Ob otzyve... 2014).

Policies of the US insurance companies named after saints have stood the test of time: The St. Louis Mutual Life Insurance Company dated 11.07.1869, the St. Nicholas Insurance Company - 9.05.1871 and the Saint Paul Fire and Marine Insurance Company - 1.11.1875.

In the next part of the study, the use of the cross as part of corporate identity of an insurance company is analysed.

\section{The Cross as an Element of Corporate Identity}

In the nineteenth century, under the active development of mutual insurance companies in Europe, business entities (legal or natural persons) uniting to provide insurance protection against particular risks (Logvinova 2009, p. 25), quickly and significantly came to benefit policyholders.

In Russia, for example, the introduction of mutual property insurance was proposed in the cities and towns of the empire. On September 20, 1855, it was 
written, "the Minister of the Interior should submit his views on this subject in the shortest possible time" (Dadkov \& Turbina 2007, p. 100). Another interesting note, by the Minister of Internal Affairs of the Committee of Ministers dated August 16, 1861, offered analytics on the basis of foreign (England, France, Austria, Prussia, Switzerland) (Vvedenii vzaimnogo... 1912) and domestic data related to issues of mutual property insurance against fire.

As R. Safuanov has said (Obshchestva... 2009, p. 16) that by participating in mutual insurance, policyholders not only retained their savings, but also helped to develop generally useful organisations. Mutual insurance companies in Poland, Ukraine, and the Russian Empire were managed by major businessmen, landlords and clergy, who actively promoted the idea of insurance by purchasing insurance products themselves.

$\mathrm{K}$. Voblyy argues that it is useful to provide the names of board members and directors, as it can sometimes impact the decision of those seeking insurance (Voblyy 2001, p. 64). E. Kolomin stressed the need to strengthen the authority of insurance, trust, and respect for it at the moment of signing the contract and issuing the insurance policy (Kolomin 2006, p. 84).

An important task of the Ukrainian economy at the end of the nineteenth century was nationalising capital through its investment in Ukrainian companies (Kolb 2013, p. 290). The clergy made a significant contribution to the development of Dniester, the first Ukrainian Mutual Insurance Company against fire, theft, and burglary. The company was based in Lviv and established according to the resolution of the Galicia vicariate dated September 15, 1892. The founding members of the company were well-known Ukrainian lawyers and public figures (Vasilik 2014). As the most affluent strata in Ukraine, representatives of the Greek Catholic clergy and intellectuals made significant financial contributions to the establishment of Dniester. These two groups respectively comprised $46.8 \%$ and $42.8 \%$ of the 350 founding members (Plisa 2005, p. 18; Klapkiv 2014, p. 58).

As of 1898, 1245 parishes and 1808 churches were insured by Dniester (Kolb 2013 , p. 290), though these numbers may be considered misleading. Some priests, as a precaution, insured only part of the church property with Dniester, while opting to diversify coverage and engage Polish or German companies.

After addressing the major financial issues, the meeting of the founders was held. Sylvester Sembratovych, of the Greek Catholic church, was elected the company's honorary president. His professional experience would explain why he may have been a good candidate: a Metropolitan of Galician Greek-Catholic Church, Archbishop of Lviv, Cardinal; a professor and dean of the Theology Faculty of Lviv University; a member of Ukrainian cultural and educational institutions; an Imperial Privy Councillor, member and twice Chairman of the Seim; and a member of the House of Lords in Vienna. After his death in 1901, this 
position was held by Count Andrey Sheptitskiy, also a Metropolitan of the Greek Catholic Church, a Ukrainian public and political figure and Archbishop of Lviv and Metropolitan of Galicia.

For proof of the Dniester Mutual Insurance Company's pre-WW I popularity, one need consider only that it insured the property of all Greek-Catholic parishes of Galicia. Dniester was also active in patronage activities. In the first 25 years of its operations, the company spent more than 500,000 krones on public needs. Dniester did not have a license for life insurance, so under the beneficial terms of the commission fee it offered its clients the products of the Florianka Krakow Insurance Company. At the same time, the two companies were competitors in the fire insurance market (Khotkevich 1918, p. 144).

Since 1893 management had been advising agents with large districts to create sub-agents through church committees, communities, local schools councils, villages and cities (Gavlich 2013, p. 15). Most of the clergy's interest in establishing the company, its patriotic course, was reflected in its symbols.

The study found that the insurer used various forms of insurance policies as an element of corporate identity, depending on the object of insurance: A - building insurance; B - movable property and animal insurance; $\mathrm{C}$ - insurance of grain, root crop insurance (Reverchuk et al. 2005, p. 179; Klapkiv \& Klapkiv 2003, p. 50). With their own example, the priests popularised the insurance institute. For example, in 1908 the insurance company issued 233,396 insurance policies, and received 2,391,541 krones in premium, and covered 244,842,169 krones worth of property. In total, 191,574 residential buildings were insured, 341,487 commercial buildings, 2,784 churches, and 1,818 parishes (Klapkiv \& Klapkiv 2003, p. 58).

The name of the company and company logo placed on insurance policies had not only the crown of the Kingdom of Galicia and Volyn depicted on it, but also the papal cross. The letterhead of the insurance company contains the inscription "In the name of the Lord" (Klapkiv \& Klapkiv 2003, p. 209-210).

With regard to Christian symbols, it is worth noting that one of the Holy Fathers of the Church - St. Clement of Alexandria, in the third century advised hiding the image in symbols, such as a fish, palm tree, dove, snake, dragon, and thus to protect the hidden idea from enemies' neglect. Images of Christians in the catacombs were mostly symbolically encrypted. Many birds had symbolic meaning, foremost among them the dove, one of the oldest Christian symbols of truth, innocence, purity, humility, calm, eternity, the immortality of the spirit, Christ, the Holy Spirit, as well as the unity of the Church, the Annunciation.

The cross is an ancient symbol of eternity, sun, immortality, suffering and, in Christianity, faith, which, according to the Roman historian Suetonius, was already well known in the first century. According to legend, the True Cross was made of four kinds of wood to symbolise the four parts of the world. 
The cross - two intersecting lines - is an ancient symbol of the Eternal Tree of Life, an ancient symbol of life, truth and salvation, taken by the ancient Christians (people of the cross, people of the life), who spread it throughout the world. As Chekal has noted, the cross is not a logo, but a symbol with a more complex structure of perception and application (Chekal 2014, p. 27).

The sign of the cross carries a lot of meanings. In particular, it is a sign of a three-dimensional Universe, of life. It portrays the Trinity underlining the importance of filial energy (the third force), Love. This is done by combining the masculine energy symbol of fire (depicted in the beliefs of all peoples by the vertical plane or a vertical column) with the symbol of a wet feminine energy (depicted by the horizontal plane), in which both parental symbols disappear, merging into a single sign of the cross - the symbol of three-dimensional space, love, a child. This is the sign of the first trinity: minus, plus, unity or mother, father, and child.

Section 60 of the Charter of the Dniester Mutual Insurance Company states that all the certificates and letters that are issued on behalf of the company, which imply an obligation, should be written or printed by the firm of the Company (Statut... 1925, p. 27). The names of the insurance company in Ukrainian, Polish, German, French, English, Romanian, and Czech languages were written in the second paragraph. It was also notes that the company's main office is located in Lviv.

\section{Conclusions}

An insurer's corporate identity is expressed through the attributes of corporate style, and a stylish, unique design of corporate identity is a necessary elemental image for any insurer. Corporate identity is a set of permanent elements of colours, images, verbal elements, typography, and design, providing visual and semantic unity for all the information the insurance company brings to the world, its internal and external appearance.

A company's logo, trademark, slogan, colour, and graphic are all a part of corporate identity, as are the design of corporate identity carriers, including insurance policy forms, insurance boards, envelopes, business cards, promotional materials.

When developing a corporate identity and using the elements of sacred art, the company should ensure that the main elements of the style are compatible with the full range of promotional products. Recently, experts in promotion and the sale of products increasingly often use symbols associated with the church and religion for their own purposes. A risk they take is in offending the religious feelings, though symbols can carry positive associations. And from this perspective it is 
pleasing to realise that Christian words, phrases, and Christian folklore are still meaningful and acceptable for modern man (Vinogradov 2014).

Moreover, it is difficult not to agree with L. Vinogradov (2014) that the ideal corporate image was created by the world's great religions. Yet this is someone else's image, and should only be used with the permission of those to whom it belongs. And even then, in order to avoid mistakes, it is worth consulting with religious experts.

It is also advisable to do a preliminary analysis of the potential risks of using elements of sacred art in corporate identity. Whether it is relevant enough, could cause discontent among certain groups and or be perceived as boring are questions that should be addressed. This study led to the conclusion that experimenting with a brand-name style is not advisable. When an advertising campaign uses images of crosses and other sacred symbols, images of guardian angels and saints, they may be seen by the religious as irreverent.

Marketers should carefully consider and weigh all the benefits and drawbacks before using such symbols of sacred art in trademarks. In any case, we must understand that not only low-quality, but simply offensive products can cast a shadow over the historical images or symbols so esteemed by the religious.

\section{Bibliography}

Akimov V., Borzykh V. (2002), Rossiyskiy opyt vzaimnogo strakhovaniya, Poligraficheskiy kombinat, Obninsk.

Broński K. (2011), Rozwój ubezpieczeń gospodarczych w Galicji w XIX wieku (zarys problematyki), Studia i Prace Wydziału Ekonomii i Stosunków Międzynarodowych no 3, Uniwersytet Ekonomiczny w Krakowie, Kraków.

Chekal A. (2014), Tserkov - eto ne brend a krest - ne logotip, http://rublev.com/interviu/ aleksei-chekal--tserkov--eto-ne-brend--a-krest--ne-logotip/print (accessed: 31.01.2017).

Dadkov V. N., Turbina K. E. (2007), Vzaimnoye strakhovaniye, Ankil, Moskwa.

Drey K. V. (2013), Transformatsiya religiynoï svidomosti u suchasnomu informatsiynomu postori, "Nauka. Religiya. Suspilstvo", no 3.

Fedorova M. V. (2014), Religioznaya kommunikatsiya: sushchnost $i$ spetsifika sovremennogo sostoyaniya, "Science Time", no 4(4).

Gavlich I. (2013), Rol strakhovikh tovaristv "Dnistra" $i$ "Karpatiï" u kreditnomu zabezpechenni kooperativnogo rukhu Skhidnoï Galichini (kinets XIX - pochatok $X X$ st.) (in:) I. Zulyak, M. Aleksievets, L. Aleksievets, M. Barmak (eds), Naukovi zapiski Ternopilskogo natsionalnogo pedagogichnogo universitetu imeni Volodimira Gnatyuka, TNPU, Ternopil.

Gubnitsyna O. (2007), Religiya i sovremennoye obshchestvo potrebleniya: vvedeniye v problem, "Zhurnal sotsiologii i sotsialnoy antropologii", vol. 10, no 1.

Instrukcya dla sub-agentow Towarzystwa wzajemnych ubezpieczeńn w Krakowie w dzialie ubezpieczen od ognia (1888), Kraków. 
Ivankin F. F. (2009), Aktsionernoye i vzaimnoye strakhovaniye v Rossii (1827-1920) Katalog, "Izdatelskiy Dom Ruchenkinykh", Moskwa.

Iwanicz-Drozdowska M. (2013), Ubezpieczenia, Polskie Wydawnictwo Ekonomiczne, Warszawa.

Kałkowski L. (2014), Historyczne polisy ubezpieczeniowe $w$ finansach $i$ w kolekcjach, "Wiadomości Ubezpieczeniowe", no 2.

Khavkina L. M. (2012), Apelyuvannya do kategorï simvolu v suchasnomu ukraïnskomu reklamnomu mifi, "Psikholingvistika", vol. 10.

Khotkevich I. (1918), Kooperatsiya v Galichini, Izdatelstvo "Soyuz" Kharkovskogo Kreditnago Soyuza Kooperativov, Kharkov.

Klapkiv M. S., Klapkiv Y. M. (2003), Vytoki natsionalnogo strakhovogo rinku Ukraïni: Monongrafiya, Kart-blansh, Ternopil.

Klapkiv Y. M. (2014), Mitropolit Andrey Sheptitskiy, Ukraïnskiy Strakhoviy Klub, Cherven. Knyt A. (2003), 200 lat ubezpieczenia, Ośrodek Karta, Warszawa.

Kolb N. (2013), Suspilno-politichna diyalnist greko-katolitskogo parafiyalnogo dukhovenstva $v$ Galichini u 90-kh rokakh XIX stolittya, Ukraïna: kulturna spadshchina. natsionalna svidomist, Derzhavnist, Vip. 23.

Kolomin E. V. (2006), Razdumia o strakhovanii, Izdatelskiy Dom "Strakhovoye revyu", Moskwa.

Komunikowanie się w biznesie (2002), H. Mruk (ed.), Wydawnictwo Akademii Ekonomicznej w Poznaniu, Poznań.

Leshchenko A. M. (2016), Khristiyanske sakralne mistetstvo yak determinanta dukhovnogo konsonansu viryanina, "Innovative solutions in modernscience", no 1(1).

Linder V. (2010), Ispolzovat veru, "Reklamodatel: teoriya i praktika", no 11.

Logvinova I. L. (2009), Vzaimnoye strakhovaniye v Rosii: osobennosti evolyutsii, Finansy i statistika, Moskwa.

Marketing instytucji finansowych (2011), M. Płonka (ed.), Wydawnictwo Uniwersytetu Ekonomicznego w Krakowie, Kraków.

Monografia Towarzystwa Wzajemnych Ubezpieczeń w Krakowie (1886), Kraków.

Novaya filosofskaya entsiklopediya: v 4tt (2001), V. S. Stepina (ed.), Mysl, Moskwa, http:// dic.academic.ru/dic.nsf/enc_philosophy/9015/95 (accessed: 31.01.2017).

Ob otzyve litsenzii na osushchestvleniye strakhovaniya subyekta strakhovogo dela, http:// www.cbr.ru/press/pr.aspx?file=05052014_151432SFR5.htm (accessed: 31.01.2017).

Obshchestva vzaimnogo strakhovaniya: retrospektiva. analiz i uchet (2009), R. M. Safuanov (ed.), Gilem, Ufa.

Plisa V. Y. (2005), Strakhuvannya, Karavela, Kijów.

Pylypenko S. G. (2012), Transformatsiya kulturi v umovakh globalizatsiï: filosofsko-antropologichniy vimir, V. N. Karazina, Kharków.

Reverchuk S. K., Siva T. V., Kubiv S. I., Vovchak O. D. (2005), Historiya strakhuvannya: pidruchnik, Znannya, Kijów.

Rutkowska M. (2006), Towarzystwa ubezpieczeń wzajemnych. Społeczne aspekty funkcjowania w ubezpieczeniach zdrowotnych, Wydawnictwo Naukowe PWN, Warszawa.

Ryzhov Y. V. (2006), Mediareligioznost: osnova budushchey religii?, "Chelovek", no 4.

Shcherbakova Y. (2007), Religioznyye simvoly v sovremennoy reklamnoy kommunikatsii, Novgorod.

Statut Tovaristva Vzajemnych Obezpechen «Dnister» vo Lvove (1925), Naukove tovarystvo imeni Shevchenka, Lviv. 
Strategie marketingowe (2002), H. Mruk (ed.), Wydawnictwo Akademii Ekonomicznej w Poznaniu, Poznań.

Towarzystwo Ubezpieczeń Wzajemnych "Florian" (2001), "Gazeta Ubezpieczeniowa”, 16 May, http://www.gu.com.pl/index.php?option=com_content\&view=article\&id=109 83\&catid=129:rynek-ubezpieczeniowy\&Itemid=151 (accessed: 31.01 .2017 ).

Ubezpieczenia gospodarcze i społeczne (2009), E. Kucka (ed.) Wydawnictwo Uniwersytetu Warmińsko-Mazurskiego w Olsztynie, Olsztyn.

Vasilik I. (2014), Uchast galitskikh pravnikiv u stvorenni ukrainskikh ekonomichnikh i finansovikh ustanov v kintsi XIX na pochatku XX stolittya, http://pravotoday.in.ua/ ua/press-centre/publications/pub-495/ (accessed: 31.01.2017).

Vinogradov L. (2014), Mozhno li ispolzovat religioznyye simvoly v reklamnykh tselyakh?, https://www.miloserdie.ru/article/mozhno-li-ispolzovat-religioznye-simvoly-vreklamnyh-celyah/«Svyatyye» brendy - kommentarii spetsialistov (accessed: 31.01.2017).

Voblyy K. G. (2001), Osnovy ekonomii strakhovaniya, Ekonomichna dumka, Ternopil.

Vvedenii vzaimnogo strakhovaniya ot ognya imushchestv $v$ gorodakh $i$ mestechkakh Imperii. Zapiska Ministra vnutrennikh del ot 16 avgusta 1861 no 1037 (1912), (in:) Obyasnitelnoy zapiski k Polozheniyu o vzaimnom zemskom strakhovanii (in:) I. O. Silatyev, M. V. Fedulov, Materialy po historii vzaimnogo strakhovaniya v Rossii, Tver.

Współczesne ubezpieczenia gospodarcze (2013), W. Sułkowska (ed.), Wydawnictwo Uniwersytetu Ekonomicznego w Krakowie, Kraków.

\section{Symbole sztuki sakralnej w identyfikacji wizualnej firm ubezpieczeniowych} (Streszczenie)

Artykuł poświęcony jest badaniu rozwoju działalności ubezpieczeniowej na Ukrainie i w Polsce pod koniec XIX i na początku XXI w. Omówiono szczególne aspekty tworzenia i stosowania elementów sztuki sakralnej identyfikacji wizualnej firm ubezpieczeniowych. Pod uwagę wzięto znaki graficzne Towarzystwa Wzajemnych Ubezpieczeń „Dniestr” we Lwowie i Towarzystwa Wzajemnych Ubezpieczeń „Florianka” w Krakowie. Podano przykłady użycia wizerunków św. Floriana, krzyża i inskrypcji „W imię Pana” do identyfikacji wizualnej firm ubezpieczeniowych.

Słowa kluczowe: towarzystwo wzajemnych ubezpieczeń, firma ubezpieczeniowa, tożsamość korporacyjna, elementy sztuki sakralnej, krzyż, św. Florian. 